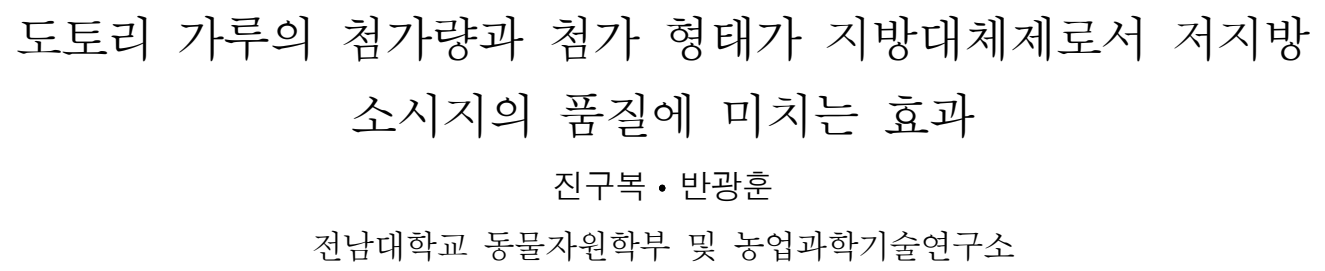

\title{
Evaluation of Two Levels and Types of Acorn Powder on Product Quality of Low-fat Sausages as a Fat Replacer
}

Koo Bok Chin and Gwang Hoon Ban

Dept. of Animal Science and Institute of Agricultural Science and Technology, Chonnam National University, Gwangju, 500-757 Korea

\begin{abstract}
Product quality of low-fat sausages (LFSs) manufactured with two types (powder and hydrated) and two levels (0.5 and 1.0\%) of Acorn powder was evaluated as a potential fat replacer. The addition of Acorn powder did not affect the product quality of LFSs $(\mathrm{P}>0.05)$, however $0.5 \%$ and hydrated Acorn was better sensory flavor than $1.0 \%$ and powder counterparts. The addition of Acorn into the LFSs decreased the expressible moisture (\%) except for $0.5 \%$ powder type and decreased Hunter L-values in LFSs. The addition of $1.0 \%$ hydrated Acorn lowered sensory saltiness than those of other LFSs and regular-fat control. These results indicated that Acorn powder can be used to manufacture LFSs as a fat replacer and $0.5 \%$ with hydrated form had better characteristics than $1.0 \%$ and powder counterparts. Future research will be performed to prevent the color change with the addition of Arcon powder in LFSs.
\end{abstract}

(Key words : Products quality, Low-fat sausages, Acorn powder, Fat replacer)

$$
\text { I. 서 론 }
$$

육가공품에서 소시지가 생산되는 비율이 전 체의 절반이 넘는 생산 규모로 발전하고 있는 실정에서 고지방 식육제품의 문제점이 대두되 고 있다(김 등, 2005). 일반 유화형 (emulsified sausage) 소시지에서는 $35 \%$ 까지 지방을 함유 할 수 있도록 허용하고 있으며 이러한 고지방 육제품의 섭취는 비만과 함께 성인병 및 동맥 경화, 암 등을 유발시키는 것으로 보고되고 있 어서 이와 같은 식품에 대한 기피현상이 일어 나고 있다(김과 유, 1994; 진 2002). 따라서 첨
가되는 지방은 소시지의 기호성에 지대한 영향 을 끼치고 있기 때문에 지방을 대체하기 위하 여 지방과 유사한 물리, 화학적 성상을 갖는 지방대체재 (fat replacer)를 이용하여 지방 함량 이 낮은 저지방 소시지 개발이 수행되고 있다 (진 2002; 국 등, 2003; 진과 왕, 2004).

도토리는 떡갈나무를 비롯한 졸참나무, 굴참 나무, 갈참나무, 돌 참나무 등과 같은 나무에서 만 자라고 이는 구황식품으로 오래전부터 식용 방법이 연구 되었으나, 근래에는 웰빙 시대에 힘입어 자연 건강식품으로 이용되고 연구 중에 있다(이, 1995). 도토리는 인체 내부의 독성을

Corresponding author : Koo Bok Chin, Department of Animal Science, Chonnam National University, PukGwangju, P.O. Box 205, Gwangju, Korea 500-600.

Tel : 062-530-2121, Fax : 062-530-2129, E-mail : kbchin@chonnam.ac.kr 
해독하는 수검 작용을 하는 기록이 있고 설사 를 자주하는 사람이 도토리를 먹으면 설사를 그치게 되는데 이는 도토리의 탄닌 성분 때문 이다. 또한 심 등 (2004)의 연구에 따르면 도토 리는 항산화 작용을 하여 인체의 위해요인을 막기도 한다고 보고하였다. 그리고 도토리는 고지혈증이나 지방간에도 효과가 있는 것으로 나타났고 전분 성분은 겔 (gel) 형성이 좋아 우 리나라에서는 오래전부터 떡이나 묵의 재료로 이용되어져 왔다(성 등, 1997). 도토리의 전분 입자는 독특한 구조와 성질을 가지므로 가열에 의한 호화, 냉각 등에 따라 겔화 특성이 달라 지는 성질이 있다 (김, 1992). 그러나 탄닌 성분 으로 인한 떫은맛이나 색 변화의 요인이 되는 물질을 제거해야 되는 번거로움이 있고 식육 분야에서 도토리의 약이성과 관련하여 많은 연 구가 아직 미비한 실정이다. 특히 소시지에 첨 가된 지방은 기호성에 지대한 영향을 끼치고 있기 때문에 지방을 제거함과 동시에 지방과 유사한 이화학적 성상을 갖는 지방대체재를 개 발하여 지방 함량이 낮은 저지방 소시지의 개 발이 시급한 실정이다.

따라서 본 연구는 도토리가루를 육가공품에 적용하기 위하여 지방대체재로서 활용하여 지 방을 제거하고 겔 형성 능력이 뛰어난 도토리 가루를 첨가한 저지방 소시지를 개발하고 품질 을 평가함으로써 도토리 가루의 지방대체재로 서의 가능성을 평가하기 위하여 실시하였다. Instron Texture Analyzer를 이용한 기계적 검사 와 관능검사를 병행하여 도토리의 첨가 형태 (가루 및 수화형태)와 첨가량 $(0.5$ 와 $1.0 \%)$ 에 따 른 최적의 조건을 이화학적, 기능적 및 조직학 적 특성을 조사함으로써 선별하고 최종적으로 도토리가루를 식육가공품에 이용할 수 있는 기 초 자료를 제시하고자 실시하였다.

\section{ㅍ. 재료 및 방법}

\section{1. 공시재료}

도토리묵가루 (함양농협, 경상남도)를 시중에 서 구입하여 분말 형태와 수화시킨 형태로 각
각 0.5 와 $1 \%$ 를 첨가하였다. 원료육은 국내산 돈육 후지 부분을 도매점에서 구입하여 과도한 지방과 결체조직을 제거한 후, 만육기 (M-12S, 한국후지 플랜트(주), 부산, 한국)로 만육한 후 실험에 사용되기 전까지 냉동 보관 하였다.

\section{2. 소시지 제조}

소시지의 제조는 Chin 등 (2004)의 방법으로 각각 유화형 및 저지방 대조구와 Gelcarin (Kappa Carrageenan, ME8121, FMC Corp, Philadelphia, PA, USA)과 대두단백질 (Isolated soy protein, Supro EX 33, The Solae Company, St. Louis, MO, USA)을 지방 대체재로 첨가한 저지방 소시지를 제조하여 비교 평가하였으며, 혼합 지방대체재는 대두단백질 $(1.5 \%)$ 과 카라기 난 $(1.0 \%)$ 을 증류수와 각각 $1: 4$ 비율로 수화시 켜 첨가하였다. Table 1 과 같은 배합비로 세절 기 (K-15, Talsa, Italy)를 이용해 세절시키고 진 공 후, 셀룰로오스 케이싱 (Securex, $28 \mathrm{~mm}$ )에 충진하였고, 훈연기 (Nu-Vu, ES-B, Food system, $\mathrm{USA}$ )에서 훈연한 후 내부 온도가 $71.7^{\circ} \mathrm{C}$ 가 되 도록 가열한 후 냉각시킨 후 분석 전까지 냉장 보관하였다.

\section{3. $\mathrm{pH}$ 및 일반 성분}

$\mathrm{pH}$ 는 고체용 $\mathrm{pH}$-meter (Mettler-Toledo, 340, Schwerzenbach, Switzerland)로 5회 반복하여 평 균값을 구하였다. 일반 성분은 $\mathrm{AOAC}$ (1995) 방 법에 의해 수분 (dry-oven 법, $102^{\circ} \mathrm{C}, 16$ 시간), 조 단백질 (Kjeltech auto system, Buchi B-322, Switzerland) 및 조지방 (Soxhlet 추출법, $50^{\circ} \mathrm{C}, 4$ 시간) 함량을 측정하였다.

\section{4. 가열 감량}

가열 감량은 (Cooking loss, CL, \%) 셀룰로오 스 케이싱 (Securex, $28 \mathrm{~mm}$ )에 충진한 소시지의 가열 전 무게를 측정하고 Smoke Chamber $(\mathrm{Nu}-$ $\mathrm{Vu}, \mathrm{ES}-\mathrm{B}, \mathrm{Food}$ System, USA)에서 훈연 및 가 열 한 후 무게를 측정하여 가열 전 후의 감량 
Table 1. Formulation of regular-and low-fat sausages containing Acorn powder

(단위 \%)

\begin{tabular}{|c|c|c|c|c|c|c|c|}
\hline & \multirow{2}{*}{$\mathrm{RFC}^{1)}$} & \multirow{2}{*}{$\mathrm{LFC}^{2)}$} & \multirow{2}{*}{$\begin{array}{l}\text { LFC } \\
+ \text { FR }\end{array}$} & \multicolumn{2}{|c|}{ Acorn Powder } & \multicolumn{2}{|c|}{ Acorn Hydrate } \\
\hline & & & & 0.5 & 1.0 & 0.5 & 1.0 \\
\hline Pork lean & 55 & 60 & 60 & 60 & 60 & $60 \%$ & $60 \%$ \\
\hline Pork backfat & 15 & $\mathbf{0}$ & $\mathbf{0}$ & $\mathbf{0}$ & $\mathbf{0}$ & $\mathbf{0}$ & $\mathbf{0}$ \\
\hline Water & 23.5 & 33.5 & 31.0 & 31.5 & 31.0 & 31.5 & 31.0 \\
\hline Fat replacer $(\mathbf{F R})^{3)}$ & $\mathbf{0}$ & $\mathbf{0}$ & 2.5 & 2.0 & 2.5 & 2.0 & 2.5 \\
\hline Gelcarin & 0 & 0 & 1.0 & 0 & 0 & 0 & 0 \\
\hline Soy protein isolate & 0 & 0 & 1.5 & 1.5 & 1.5 & 1.5 & 1.5 \\
\hline Acorn powder & 0 & 0 & 0 & 0.5 & 1.0 & 0 & 0 \\
\hline Acorn hydrate & 0 & 0 & 0 & 0 & 0 & 0.5 & 1.0 \\
\hline Non-meat Ingredient & 6.5 & 6.5 & 6.5 & 6.5 & 6.5 & 6.5 & 6.5 \\
\hline Salt & 1.3 & 1.3 & 1.3 & 1.3 & 1.3 & 1.3 & 1.3 \\
\hline Sugar & 1.5 & 1.5 & 1.5 & 1.5 & 1.5 & 1.5 & 1.5 \\
\hline STPP $^{5)}$ & 0.4 & 0.4 & 0.4 & 0.4 & 0.4 & 0.4 & 0.4 \\
\hline $\mathrm{NFDM}^{6}{ }^{6}$ & 1.0 & 1.0 & 1.0 & 1.0 & 1.0 & 1.0 & 1.0 \\
\hline $\mathrm{MD}^{7)}$ & 1.0 & 1.0 & 1.0 & 1.0 & 1.0 & 1.0 & 1.0 \\
\hline Spice\#5 & 1.0 & 1.0 & 1.0 & 1.0 & 1.0 & 1.0 & 1.0 \\
\hline $\mathrm{SE}^{8)}$ & 0.05 & 0.05 & 0.05 & 0.05 & 0.05 & 0.05 & 0.05 \\
\hline Cure blend & 0.25 & 0.25 & 0.25 & 0.25 & 0.25 & 0.25 & 0.25 \\
\hline Total (\%) & 100.0 & 100.0 & 100.0 & 100.0 & 100.0 & 100.0 & 100.0 \\
\hline
\end{tabular}

${ }^{1)}$ RFC: regular-fat sausage control.

2) LFC: low-fat sausages (LFS) control.

3) FR: fat replacer, gelcarin $1.0 \%$ and soy protein isolate $1.5 \%$.

5) STPP: sodium tripolyphosphate.

6) NFDM: non-fat dry milk.

7) MD: malto-dextrin.

8) $\mathrm{SE}$ : sodium erythorbate.

(\%)을 구하였다.

\section{5. 유리 수분양}

Jauregui 등 (1981)의 방법을 변형하여 유리 수분의 양 (Expressible moisture, EM, \%)을 측정 하였다. 소시지를 $1.5 \mathrm{~g}$ 정도 잘라서 여과지 (Whatman \#3)로 감싸고 원심분리기 (VS-5500, Vision Scientific Co. Ltd, Korea)로 3,000 rpm으 로 15 분간 원심 분리시킨 후 유리 수분의 양 (expressible moisture, EM\%)을 측정하였다.

\section{6. 색도 측정}

색도 (Color)는 Chroma Meter (CR-200, Minolta
Corporation, Ramsey, NJ)를 이용하여 명도 (lightness), 적색도 (redness), 황색도 (yellowness) 를 각각 측정하였다. 소시지를 적당하게 잘라 서 앞면, 뒷면, 옆면을 각각 4회씩 측정 하였 고, 이때 사용된 백색 표면의 표준 $\mathrm{L}, \mathrm{a}, \mathrm{b}$ 값 은 각각 $93.7,5.3,-2.1$ 로 나타났다.

\section{7. 조직감 검사}

조직감 측정 (Texture profile analysis, $\mathrm{TPA})$ 은 Bourne (1978)의 방법으로 Instron Universal Testing Machine (Model 3344, Canton, MA, USA) 을 이용하여 Texture profile analysis (TPA)를 실 시하였으며, 시료는 $1.3 \mathrm{~cm}$ 로 균일하게 자른 뒤, $1.25 \mathrm{~cm}$ 직경의 puncture로 coring하여 준비하였 
다. 경도 (hardness), 탄력성 (springiness), 검성 (gumminess), 저작성 (chewiness), 응집성 (cohesiveness) 을 측정하였고, 실험조건은 $500 \mathrm{~N} \mathrm{Load} \mathrm{cell에}$ compression probe를 장착하여 cross speed는 300 $\mathrm{mm} / \mathrm{min}$ 로 하고, 압착정도는 $75 \%$ 로 설정하였다.

\section{8. 관능 검사}

냉장 보관된 소시지를 진공포장지에 담아서 끓는 물에 6분 정도 가열하여 관능 검사 (sensory evaluation)를 실시하였다. 7 8명의 훈련되지 않 은 관능요원으로 하여 향미 (flavor), 조직감 (texture), 다즙성 (juiciness), 색도 (color), 염도 (saltiness) 및 총괄적 (overall acceptance) 평가를 관능용지 (sensory ballot)에 8-point hedonic scale 로 표시하여 점수가 높을수록 선호도가 높은 것으로 평가하였다.

\section{9. 미생물 검사}

미생물 검사 (microbial test)는 총균수 (Total plate count agar, TPC)와 대장균군수(Violet Red Bile Agar, $\mathrm{VRB}$ )를 측정하였다. 각각의 평판배 지에 희석한 시료를 $0.1 \mathrm{ml}$ 도포한 후, $37^{\circ} \mathrm{C}$ 에 서 48시간 배양하였고, 균락수를 계산하여 $\mathrm{g}$ 당 균락수를 $\log$ 로 환산하여 최종 $\log$ colony form unit (cfu/g)으로 평가하였다.

\section{0. 통계처리}

실험 결과에 대한 통계처리(statistical analysis) 는 SPSS 12.0 program(2003)을 이용하여 3번 반복 실험한 결과를 도토리가루의 함량 $(0.5$, $1.0 \%$ )과 형태 (분말, 수화물)에 따라서 이원배 치 (Two-way ANOVA) 분산분석을 실시하여 상 호작용을 보았으며, 요인간 상호작용이 있을 경우 각 도토리가루 형태내에서 함량을, 그리 고 각 함량내에서 형태를 비교하였고, 상호작 용이 없을 경우에 항목별 측정 결과를 총체적 인 평균값 (pooled means)으로 정리하여 함량과 형태에 따른 유의차를 평가하였다. 또한, 각 처 리구와 저지방 대조구와 유의적인 차이를 보이
는 고지방 및 저지방 처리구를 선별하기 위하

여 Dunnett's T-test를 실시하였다.

\section{III. 결과 및 고찰}

\section{1. 도토리가루의 함량과 형태에 따른 차이분석}

이원배치 분산분석 결과 도토리가루의 함량 과 형태에 따른 상호작용의 유의차가 발견되지 않았으며 $(\mathrm{P}>0.05)$, 따라서 총체적인 평균값으로 정리하여 도토리 함량과 형태로 각각 구분한 결과는 Table 2와 같다. 대부분의 이화학적, 조 직감 및 관능적인 성상에서 차이를 보이지 않 았으나(P>0.05), 향미에 있어서 수화형태, 그리 고 $0.5 \%$ 가 $1.0 \%$ 보다는 선호도를 나타내었다. 이와 같은 결과는 도토리가루의 첨가형태(가루 및 수화 $)$ 와 함량 $(0.5,1.0 \%)$ 에는 저지방 소시지 의 품질에 큰 영향을 주지 않음을 시사한다.

\section{2. 저지방 소시지를 대조구로 Dunnett's-T test 한 결과}

지방대체재를 첨가하지 않은 저지방 소시지 를 대조구로 고지방 및 저지방 처리구와의 품 질특성의 유의차를 보이는 처리구를 평가하기 위해서 Dunnett's T-test을 이용한 통계분석을 실시하였고 결과는 Tables 3 6과 같다.

(1) $\mathrm{pH}$ 및 일반 성분

제조한 소시지의 $\mathrm{pH}$ 및 일반성분의 결과는 Table 3과 같다. $\mathrm{pH}$ 는 유화형 소시지에서 6.04, 저지방 대조구 5.91 , 그리고 지방대체재를 첨가 한 저지방 대조구에서는 5.93으로 나타났고, 유 화형 대조구와 비교해 볼 때, 저지방 소시지들 은 유의적인 차이를 보이지 않았다 $(\mathrm{P}>0.05)$. 수 분은 유화형 소시지에서 $66.3 \%$ 로 저지방소시지 의 76.4 78.1\%와 비교시 유의적으로 낮았는데 $(\mathrm{P}<0.05)$, 이는 제조시 첨가한 지방의 함량차이 에 기인한 결과로 평가 된다 (Table 1). 지방은 유화형 소시지에서 $14.6 \%$, 저지방 소시지에서 는 1.75 2.31\%로 감소하였고, 유화형 소시지는 약 $15 \%$ 의 지방을 첨가하여 제조하였기 때문에, 
Table 2. Pooled means of $\mathrm{pH}$, proximate compositions, functional, textural and sensory properties of low-fat sausages with two types and levels of Acorn as a fat replacer

\begin{tabular}{lccccc}
\hline \multirow{2}{*}{ Parameters } & \multicolumn{2}{c}{ Types } & & \multicolumn{2}{c}{ Levels } \\
\cline { 2 - 3 } \cline { 5 - 6 } & Powder & Hydrate & & $0.5 \%$ & $1.0 \%$ \\
\hline \hline pH & $5.95^{\mathrm{a} 1)}$ & $5.94^{\mathrm{a}}$ & & $5.90^{\mathrm{a}}$ & $5.99^{\mathrm{a}}$ \\
Moisture (\%) & $77.1^{\mathrm{a}}$ & $76.6^{\mathrm{a}}$ & & $76.6^{\mathrm{a}}$ & $77.2^{\mathrm{a}}$ \\
Fat (\%) & $2.00^{\mathrm{a}}$ & $2.14^{\mathrm{a}}$ & & $2.03^{\mathrm{a}}$ & $2.10^{\mathrm{a}}$ \\
Protein (\%) & $13.8^{\mathrm{a}}$ & $13.4^{\mathrm{a}}$ & & $13.9^{\mathrm{a}}$ & $13.3^{\mathrm{a}}$ \\
\hline Expressible moisture (EM, \%) & $28.0^{\mathrm{a}}$ & $26.2^{\mathrm{a}}$ & & $27.8^{\mathrm{a}}$ & $26.3^{\mathrm{a}}$ \\
Cooking loss (CL, \%) & $9.12^{\mathrm{a}}$ & $8.37^{\mathrm{a}}$ & & $9.03^{\mathrm{a}}$ & $8.46^{\mathrm{a}}$ \\
\hline Hardness (gf) & $5505^{\mathrm{a}}$ & $5262^{\mathrm{a}}$ & & $5171^{\mathrm{a}}$ & $5596^{\mathrm{a}}$ \\
Fracturability (gf) & $3420^{\mathrm{a}}$ & $3292^{\mathrm{a}}$ & & $3257^{\mathrm{a}}$ & $3456^{\mathrm{a}}$ \\
Springiness (cm) & $0.39^{\mathrm{a}}$ & $0.38^{\mathrm{a}}$ & & $0.40^{\mathrm{a}}$ & $0.37^{\mathrm{a}}$ \\
Gumminess & $1416^{\mathrm{a}}$ & $1420^{\mathrm{a}}$ & & $1443^{\mathrm{a}}$ & $1393^{\mathrm{a}}$ \\
Chewiness & $563^{\mathrm{a}}$ & $550^{\mathrm{a}}$ & & $589^{\mathrm{a}}$ & $523^{\mathrm{a}}$ \\
Cohesiveness & $0.26^{\mathrm{a}}$ & $0.27^{\mathrm{a}}$ & & $0.27^{\mathrm{a}}$ & $0.25^{\mathrm{a}}$ \\
\hline Sensory flavor & $5.27^{\mathrm{b}}$ & $6.07^{\mathrm{a}}$ & & $6.03^{\mathrm{a}}$ & $5.30^{\mathrm{b}}$ \\
Sensory texture & $5.33^{\mathrm{a}}$ & $6.43^{\mathrm{a}}$ & & $5.80^{\mathrm{a}}$ & $5.97^{\mathrm{a}}$ \\
Sensory juiciness & $5.77^{\mathrm{a}}$ & $6.13^{\mathrm{a}}$ & & $6.13^{\mathrm{a}}$ & $5.77^{\mathrm{a}}$ \\
Sensory color & $3.47^{\mathrm{a}}$ & $3.63^{\mathrm{a}}$ & & $4.00^{\mathrm{a}}$ & $3.10^{\mathrm{a}}$ \\
Sensory saltiness & $5.87^{\mathrm{a}}$ & $5.57^{\mathrm{a}}$ & & $5.87^{\mathrm{a}}$ & $5.57^{\mathrm{a}}$ \\
\hline Overall sensory acceptance & $5.27^{\mathrm{a}}$ & $5.87^{\mathrm{a}}$ & & $5.80^{\mathrm{a}}$ & $5.33^{\mathrm{a}}$ \\
\hline I) & & & &
\end{tabular}

1) All values are the pooled mean.

a-b Means having same superscript within same factor (types or levels) are not different $(\mathrm{P}>0.05)$.

Table 3. $\mathrm{pH}$ and proximate analysis of regular-fat and low-fat sausages as affected by two levels and types of Acorn powder

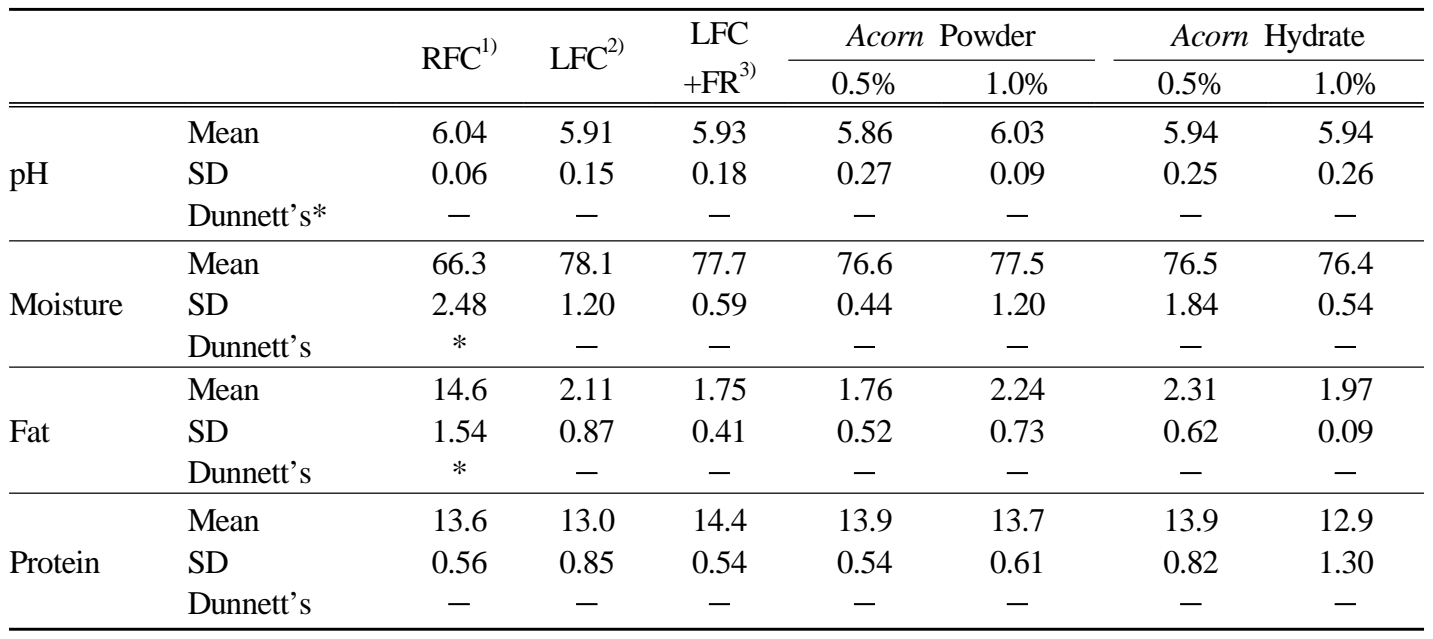

Dunnett's-T test, significant comparisons are indicated by an asterisk ( $<<0.05$, LFC vs. Treatment):

* Means significant differences as compared to that of regular-fat control in Dunnett's T-test $(\mathrm{p}<0.05)$.

1) RFC: regular-fat sausage control (15\% fat).

2) LFC: low-fat sausage (LFS) control ( $<3 \%$ fat).

3) FR: fat replacer (gelcarin and soy protein isolate, $2 \sim 2.5 \%$ ). 
첨가하지 않은 저지방 소시지에 비해 높은 지 방의 함량을 보였다. 한편, 단백질 함량은 12.9 14.4\%로 유화형 대조구와 비교했을 때, 저지 방 소시지의 단백질 함량은 유의적인 차이를 보이지 않았다 $(\mathrm{P}>0.05)$. 진과 왕 $(2004)$ 은 키토 산 함량을 달리하여 저지방소시지를 제조한 결 과, $\mathrm{pH}$ 가 5.52 5.75로 키토산의 첨가로 $\mathrm{pH}$ 가 낮아졌으며 본 연구의 저지방소시지 $\mathrm{pH}$ 보다 는 다소 낮은 경향을 보인 반면에, 유화형 소 시지는 유사하였다. 한편, 진 등 (2005)의 자몽 종자 추출물을 첨가한 저지방 소시지의 일반성 분은 수분 73 76\%, 지방 1.3 2.4\% 그리고 단백 질은 15.8 17.1\%를 나타내어 도토리 가루를 첨 가한 저지방 소시지와 큰 차이를 보이지 않았 으나 단백질 함량이 높은 편이었다.

\section{(2) 유리 수분량과 가열 감량}

보수력을 측정하기 위해 분석한 유리 수분 (expressible moisture, EM, \%)은 유화형 대조구 가 $23.1 \%$ 로 가장 낮은 수치를 나타냈고, 저지 방 소시지 대조구는 $38.8 \%$ 를 나타내어 유화형 대조구와 유의차를 보였다 (Table 4$)(\mathrm{P}<0.05)$. 반 면에, 도토리가루를 $1 \%$ 가루형태를 첨가하거나 0.5 1.0\% 수화형태로 첨가한 처리구는 기존의 사용한 카라기난과 대두단백질의 혼합보다 더 낮은 유리 수분량을 보임으로써 보수력이 높아 짐을 알 수 있었다 $(\mathrm{P}<0.05)$. 이는 도토리의 전 분 특성이 지방대체제의 역할을 하여 보수력을 증진시킨 것으로 사료되며 수화형태가 더 보수 력에 더 효율적으로 작용함을 사사한다. 이와 관련하여 소시지 제조에 첨가한 물질에 따라

Table 4. Physico-chemical properties of regular-fat and low-fat sausages as affected by two levels and types of Acorn powder

\begin{tabular}{|c|c|c|c|c|c|c|c|c|}
\hline & & \multirow{2}{*}{$\mathrm{RFC}^{1)}$} & \multirow{2}{*}{$\mathrm{LFC}^{2)}$} & \multirow{2}{*}{$\begin{array}{c}\text { LFC } \\
+\mathrm{FR}^{3)}\end{array}$} & \multicolumn{2}{|c|}{ Acorn Powder } & \multicolumn{2}{|c|}{ Acorn Hydrate } \\
\hline & & & & & $0.5 \%$ & $1.0 \%$ & $0.5 \%$ & $1.0 \%$ \\
\hline \multirow{3}{*}{$\mathrm{EM}^{4)}$} & Mean & 23.1 & 38.8 & 28.8 & 29.5 & 26.4 & 26.1 & 26.2 \\
\hline & SD & 3.63 & 4.87 & 6.97 & 6.53 & 1.91 & 1.67 & 1.66 \\
\hline & Dunnett's ${ }^{*}$ & $*$ & - & - & - & $*$ & $*$ & $*$ \\
\hline \multirow{3}{*}{$\mathrm{CL}^{5)}$} & Mean & 9.10 & 9.83 & 8.60 & 9.36 & 8.88 & 8.71 & 8.03 \\
\hline & SD & 1.01 & 2.31 & 2.75 & 2.67 & 2.97 & 2.93 & 3.29 \\
\hline & Dunnett's & - & - & - & - & - & - & - \\
\hline \multirow{3}{*}{$L^{6)}$} & Mean & 70.6 & 69.8 & 67.1 & 63.6 & 61.8 & 63.8 & 62.8 \\
\hline & SD & 1.11 & 4.20 & 1.46 & 0.85 & 0.91 & 1.00 & 1.59 \\
\hline & Dunnett's & - & - & - & $*$ & $*$ & $*$ & $*$ \\
\hline \multirow{3}{*}{$a^{7)}$} & Mean & 13.2 & 13.1 & 13.4 & 12.6 & 12.4 & 12.8 & 13.1 \\
\hline & SD & 1.15 & 0.91 & 1.37 & 1.02 & 1.16 & 1.36 & 1.82 \\
\hline & Dunnett's & - & - & - & - & - & - & - \\
\hline \multirow{3}{*}{$b^{8)}$} & Mean & 6.17 & 5.93 & 6.07 & 4.87 & 5.33 & 4.90 & 5.50 \\
\hline & SD & 0.84 & 0.42 & 0.60 & 0.65 & 0.15 & 0.46 & 0.60 \\
\hline & Dunnett's & - & - & - & - & - & - & - \\
\hline
\end{tabular}

Dunnett's-T test, significant comparisons are indicated by an asterisk $(\mathrm{p}<0.05$, LFC vs. Treatment): * Means significant differences as compared to that of regular-fat control in Dunnett's T-test $(\mathrm{p}<0.05)$.

1) RFC : regular-fat sausage control (15\% fat).

2) LFC : low-fat sausage (LFS) control ( $<3 \%$ fat).

3) FR : fat replacer (gelcarin and soy protein isolate, $2 \sim 2.5 \%$ ).

4) EM : expressible moisture.

5) CL : cooking loss.

6) L : lightness.

7) a : redness.

8) b : yollowness. 
보수력에 미치는 영향이 달라지는데 이에 관한 연구로는 류 등 (2003)이 소시지에 홍국을 첨가 하여 제조한 연구에서는 첨가한 홍국이 소시지 의 보수력에 영향을 미치지 않은 반면, 진과 왕 (2004)의 연구에서는 소시지에 첨가한 키토 산 $(30 \sim 50 \mathrm{kDa}, 0.3$ 과 $0.6 \%)$ 이 소시지의 보수력 에 영향을 주어 낮은 보수력을 나타내었다. 반 면 가열 감량 (cooking loss, CL, \%)은 저지방 소시지 모두 유화형 소시지와 비교했을 때, 유 의적 차이를 나타내지 않았고 도토리가루의 첨 가 또한 영향을 주지 않았다 $(\mathrm{P}>0.05)$. 이는 지 방대체제를 첨가하지 않은 대조구와도 차이를 보이지 않음으로써 지방대체재 이외의 다른 첨 가물과의 상호작용에 더 기인한 것으로 평가된 다.

\section{(3) 색도 측정}

색도 측정 (color)에서 도토리 첨가에 의한 발 색효과는 외관상으로도 구별하기 쉬울 정도로 두드러지게 나타났다 (Table 4). 도토리 가루의 발색 효과는 탄닌 성분으로 인한 색의 변화로 보고되고 있고, 소시지의 색을 비교적 어둡게 하여 색도에 영향을 미치는 것으로 평가되었 다. 특히, 고지방 및 유화형 대조구와 비교한 결과, 도토리를 첨가한 소시지 모두 유의적인 차이를 보이며 낮은 명도 값을 나타냈다 $(\mathrm{P}<0.05)$. 반면 적색도와 황색도는 유의적 차이 를 나타내지 않았다 $(\mathrm{P}>0.05)$. 류 등 (2003)은 소 시지에 첨가한 홍국이 쉽게 변질되는 표면 색 상을 개선시킬 수 있다고 보고하였고, 진 등 (2005)은 젖산나트름 (3.3\%)이나 자몽 종자추출 물 $(0.1 \sim 0.3 \%)$ 등의 첨가가 색도에 뚜렷한 변화 를 주지 않아 도토리 가루를 첨가한 저지방소 시지와는 대조를 이루었다. 이와 같은 도토리 가루의 첨가로 인한 색도의 변화를 방지 할 수 있는 가공방법이 필요할 것으로 보인다.

\section{(4) 조직감 검사}

조직감 검사 (texture profile analysis, TPA)의 기계적 검사 결과에서 유화형 소시지의 경도 (hardness), 탄력성 (Springiness), 응집성 (Cohesiveness), 검성 (Gumminess)의 값은 저지방 소시
지와 유의적인 차이를 나타내지 않았다 $(\mathrm{P}>0.05$, Table 5). 특히, 도토리 가루의 첨가형태나 첨가 량에 따른 저지방 소시지도 차이를 보이지 않 음에 따라 도토리 가루의 첨가는 저지방 소시 지의 조직감에 영향을 미치지 않은 것으로 판 단된다. 정 등 (2003)은 깻잎을 첨가한 소시지를 만들어 조직감을 측정한 결과, 뭉침성이 낮아 지는 결과를 나타내었다고 보고하였고, 또한 최 등 (2003)은 녹차를 첨가한 소시지 제조에 관한 연구에서, 녹차를 첨가할 경우 경도와 저 작성이 감소한다고 보고하였다. 깻잎과 녹차의 첨가가 소시지의 조직감에 영향을 준 반면에, 도토리 가루의 첨가는 조직감 저하를 일으키지 않은 것으로 평가되어 지방대체재로서 적합할 것으로 판단된다. 조와 김 (2000)은 도토리와 메 밀전분을 이용하여 텍스쳐를 측정하였으며, 도 토리가 전분에 비하여 경도와 검성이 크다고 보고하여 이것이 조직감에 영향을 준 것으로 판단된다.

\section{(5) 관능 검사}

관능 검사 (sensory evaluation)는 훈련되지 않 은 관능요원이 향미 (flavor), 조직감 (texture), 다 즙성 (juiciness), 색도 (color), 염도 (saltiness), 및 총괄적 (overall acceptance)인 평가를 실시하였 고, 그 결과는 Table 6과 같다. 관능검사 결과 중 색도에서 Hunter color value와 마찬가지로 도토리 가루를 첨가한 처리구가 저지방대조구 와 비교하여 차이를 보였으나 $0.5 \%$ 의 수화형태 는 비교적 그 차이가 미미하였다. 다즙성과 조 직감에서는 유의적인 차이는 보이지 않았으나 유화형 소시지가 가장 높은 점수를 보였다. 한 편, 보수성 측정결과에서도 알 수 있듯이 도토 리 가루를 첨가한 소시지는 보수성이 유지됨에 따라 다즙성과 이로 인한 탄력성 증진이 연관 되어 조직감에 영향을 주었을 것으로 예상되 며, 그 결과 선호도 또한 높게 나타났다. 염도 는 수화 형태로 $1.0 \%$ 첨가한 소시지에서 가장 낮게 나타났다. 이는 도토리의 탄닌 성분의 쓴 맛이 염도를 무디게 한 결과라고 사료되며, 총 괄적으로 볼 때 도토리를 첨가한 소시지는 색 도만 개선된다면, 기존의 소시지와 유사한 관 
Table 5. Textural properties of regular-fat and low-fat sausage as affected by two levels and typess of Acorn powder

\begin{tabular}{|c|c|c|c|c|c|c|c|c|}
\hline & \multirow{2}{*}{$\mathrm{RFC}^{1)}$} & \multirow{2}{*}{$\mathrm{LFC}^{2)}$} & \multirow{2}{*}{$\begin{array}{c}\mathrm{LFC} \\
+\mathrm{FR}^{3)} \\
\end{array}$} & \multicolumn{2}{|c|}{ Acorn Powder } & \multicolumn{2}{|c|}{ Acorn Hydrate } \\
\hline & & & & & $0.5 \%$ & $1.0 \%$ & $0.5 \%$ & $1.0 \%$ \\
\hline \multirow{3}{*}{ Hard $^{4)}$} & Mean & 4008 & 4721 & 3994 & 5127 & 5882 & 5213 & 5309 \\
\hline & & 601 & 1590 & 342 & 679 & 966 & 1126 & 1380 \\
\hline & Dunnett's* & - & - & - & - & - & - & - \\
\hline \multirow{3}{*}{ Sprin $^{5)}$} & Mean & 0.33 & 0.34 & 0.37 & 0.37 & 0.41 & 0.43 & 0.34 \\
\hline & SD & 0.01 & 0.08 & 0.05 & 0.11 & 0.08 & 0.08 & 0.03 \\
\hline & Dunnett's & - & - & - & - & - & - & - \\
\hline \multirow{3}{*}{ Gum' } & Mean & 1002 & 1313 & 981 & 1363 & 1468 & 1521 & 1318 \\
\hline & SD & 176 & 543 & 228 & 411 & 481 & 488 & 413 \\
\hline & Dunnett's & - & - & - & - & - & - & - \\
\hline \multirow{3}{*}{ Chew $^{7)}$} & Mean & 331 & 519 & 368 & 541 & 585 & 637 & 461 \\
\hline & SD & 63.3 & 353 & 113 & 305 & 273 & 207 & 181 \\
\hline & Dunnett's & - & - & - & - & - & - & - \\
\hline \multirow{3}{*}{ Cohes $^{8}$} & Mean & 0.24 & 0.26 & 0.25 & 0.26 & 0.25 & 0.29 & 0.25 \\
\hline & SD & 0.01 & 0.02 & 0.05 & 0.05 & 0.04 & 0.02 & 0.02 \\
\hline & Dunnett's & - & - & - & - & - & - & - \\
\hline
\end{tabular}

Dunnett's-T test, significant comparisons are indicated by an asterisk $(\mathrm{p}<0.05$, LFC vs. Treatment): * Means significant differences as compared to that of regular-fat control in Dunnett's T-test $(\mathrm{p}<0.05)$.

1) RFC: regular-fat sausage control (15\% fat).

2) LFC: low-fat sausage (LFS) control ( $<3 \%$ fat).

3) FR: fat replacer (gelcarin and soy protein isolate, $2 \sim 2.5 \%$ ).

4) Hard: hardness (gf).

5) Sprin: springiness $(\mathrm{cm})$

6) Gum: gumminess.

7) Chew: chewiness.

${ }^{8)}$ Cohes: cohesiveness.

Table 6. Sensory evaluation of regular-fat and low-fat sausage as affected by levels and types of Acorn powder

\begin{tabular}{|c|c|c|c|c|c|c|c|c|}
\hline & & \multirow{2}{*}{$\mathrm{RFC}^{1)}$} & \multirow{2}{*}{$\mathrm{LFC}^{2)}$} & \multirow{2}{*}{$\begin{array}{c}\text { LFC } \\
+\mathrm{FR}^{3)}\end{array}$} & \multicolumn{2}{|c|}{ Acorn Powder } & \multicolumn{2}{|c|}{ Acorn Hydrate } \\
\hline & & & & & $0.5 \%$ & $1.0 \%$ & $0.5 \%$ & $1.0 \%$ \\
\hline \multirow{3}{*}{ Flavor } & Mean & 6.73 & 6.27 & 6.07 & 5.60 & 4.93 & 6.47 & 5.56 \\
\hline & SD & 0.64 & 0.64 & 0.90 & 0.69 & 0.12 & 0.50 & 0.51 \\
\hline & Dunnett's* & - & - & - & - & - & - & - \\
\hline \multirow{3}{*}{ Texture } & Mean & 7.07 & 6.20 & 6.40 & 5.27 & 5.40 & 6.33 & 6.51 \\
\hline & SD & 1.01 & 1.39 & 0.53 & 1.62 & 0.53 & 0.58 & 0.50 \\
\hline & Dunnett's & - & - & - & - & - & - & - \\
\hline \multirow{3}{*}{ Juiciness } & Mean & 7.13 & 6.20 & 6.73 & 6.13 & 5.40 & 6.13 & 6.04 \\
\hline & SD & 0.23 & 1.39 & 0.46 & 0.81 & 0.53 & 0.81 & 1.00 \\
\hline & Dunnett's & - & - & - & - & - & - & - \\
\hline \multirow{3}{*}{ Color } & Mean & 6.93 & 5.87 & 6.60 & 3.47 & 3.47 & 4.53 & 2.58 \\
\hline & SD & 0.90 & 0.23 & 0.69 & 0.50 & 0.81 & 0.81 & 0.52 \\
\hline & Dunnett's & - & - & - & $*$ & $*$ & - & $*$ \\
\hline \multirow{3}{*}{ Saltiness } & & 6.60 & 6.80 & 6.67 & 5.73 & 6.00 & 6.00 & 4.71 \\
\hline & SD & 0.53 & 0.35 & 0.58 & 0.46 & 0.00 & 0.00 & 0.62 \\
\hline & Dunnett's & - & - & - & - & - & - & $*$ \\
\hline
\end{tabular}

Dunnett's-T test, significant comparisons are indicated by an asterisk $(\mathrm{p}<0.05$, LFC vs. Treatment): * Means significant differences as compared to that of regular-fat control in Dunnett's T-test $(\mathrm{p}<0.05)$.

1) RFC: regular-fat sausage control (15\% fat).

2) LFC: low-fat sausage (LFS) control $(<3 \%$ fat).

3) FR: fat replacer (gelcarin and soy protein isolate, $2 \sim 2.5 \%$ ). 
Table 7. Microbial counts of total bacteria and Enterobacteriaceae in regular-and low-fat sausages

(unit: $\log \mathrm{cfu} / \mathrm{g}$ )

\begin{tabular}{|c|c|c|c|c|c|c|c|}
\hline \multirow{2}{*}{ Parameters } & \multirow{2}{*}{ RFC* } & \multirow{2}{*}{ LFC* } & \multirow{2}{*}{$\mathrm{LFC}+\mathrm{FR}^{*}$} & \multicolumn{2}{|c|}{ Acorn Powder } & \multicolumn{2}{|c|}{ Acorn Hydrated } \\
\hline & & & & $0.5 \%$ & $1.0 \%$ & $0.5 \%$ & $1.0 \%$ \\
\hline $\mathrm{TPC}^{1)}$ & $<2^{3)}$ & $<2$ & $<2$ & $<2$ & $<2$ & $<2$ & $<2$ \\
\hline $\mathrm{VRB}^{2)}$ & $<2$ & $<2$ & $<2$ & $<2$ & $<2$ & $<2$ & $<2$ \\
\hline
\end{tabular}

* Same as in Table 1

1) TPC: total plate count agar for total bacteria

2) VRB: violet red bile (VRB) agar for Enterobacteriaceae

3) < 2: not detected at the level of 2 log colony form unit/g ( $<100$ cells/g).

능성상으로 제조될 수 있다고 평가되었다. 특 히, 수화한 형태로 첨가할 경우, 제품의 안정성 을 증진시키게 되고 또한 $0.5 \%$ 보다 $1.0 \%$ 가 안 정한 형태의 수분의 함량이 더욱 증가되기 때 문에 제품의 안정성이 더욱 증진될 수 있다. 한편, 도토리 가루를 첨가한 식품제조에 관한 연구에서 김와 조 (2000)는 도토리 가루를 첨가 한 떡에 대한 관능 평가에서 $10 \%$ 의 도토리 가 루첨가가 선호도가 높아 적합한 첨가량으로 보 고하였다.

\section{(6) 미생물 검사}

제조한 소시지의 위생 상태를 평가하기 위해 실시한 미생물 검사 (microbial test)는 총균수와 대장균군수를 측정하여 평가하였다. 유화형 소 시지와 저지방소시지 모두 100 배 희석한 시료 를 도포한 평판배지에서 균락 (colony)이 나타나 지 않아 $\log$ colony form unit $(\mathrm{CFU}) / \mathrm{g}$ 값이 2 이 하로 위생적인 제품으로 평가되었고 도토리가 루를 첨가함에 따라 차이도 보이지 않았다 (Table 7).

$$
\text { IV. 요 약 }
$$

도토리 가루를 각각 첨가 형태 (분말, 수화)와 첨가량 $(0.5,1.0 \%)$ 을 달리하여 저지방 소시지를 제조하였고, 품질검사를 실시하였다. 도토리가 루의 첨가형태나 첨가량은 대부분의 항목에서 는 차이를 보이지 않은 반면 관능적인 향미분 석에서 수화형태가 가루보다 그리고 첨가량에
서 $0.5 \%$ 가 $1.0 \%$ 보다 선호하는 경향을 보였다. $\mathrm{pH}$, 일반성분, 가열 감량에서 도토리 가루를 첨가한 저지방 소시지는 저지방이나 유화형 대 조구와 비교했을 때, 유의적인 차이를 나타내 지 않았다 $(\mathrm{P}>0.05)$. 반면 유리수분의 경우 도토 리가루의 첨가는 기존의 지방대체재 첨가구나 유화형 대조구보다 더 낮은 유리 수분함량을 보임으로써 보수력을 증진시켰다. 색도에서는 유화형 및 저지방 대조구와 지방대체재를 첨가 한 저지방소시지는 유의적인 차이를 나타내지 않은 반면에, 도토리 가루를 첨가한 저지방 소 시지의 경우, 유의적인 차이를 보이며 낮은 명 도 값을 나타냈다 $(\mathrm{P}<0.05)$. 조직감 검사결과에 서는 도토리 첨가형태나 첨가량에 의한 차이를 보이지 않았다 $(\mathrm{P}>0.05)$. 관능검사에서는 유화형 소시지를 가장 선호하는 것으로 평가되었고, 도토리 가루를 첨가한 소시지의 경우에도 색도 를 제외한 대부분의 관능성상이 유사하였으나 $1 \%$ 의 수화형태는 비교적 식염맛에서 낮은 점 수를 보였다. 미생물 검사 결과에서는 유화형 소시지와 저지방 소시지 모두 검출되지 않아 위생상태가 양호한 것으로 평가되었다. 이와 같은 결과를 종합하여 볼 때, 저지방 소시지에 도토리 가루를 첨가함으로써 보수력을 증진시 킬 수 있었고, 색도 이외에 다른 이화학적 및 조직학적인 차이를 보이지 않음에 따라 지방 대체재로 사용가능하다고 평가되었다. 이와 같 은 결과에서 볼 때 $0.5 \%$ 의 첨가가 적당하고 가 루형태보다 수화형태가 더 효과적인을 알 수 있었다. 다만 도토리 첨가에 따른 명도가 낮아 
지는 단점을 보완한다면 저지방 소시지의 대체 제로 유용하게 사용할 수 있을 것으로 판단된 다.

$$
\mathrm{V} \text {. 사 사 }
$$

본 연구는 한국학술진흥재단 젊은과학자 연 구활동지원-유형1(과제번호; 2003-F00019)에 의 해서 수행되었으며 이에 감사드립니다.

\section{VI. 인 용 문 헌}

1. AOAC. 1995. Official Method of Analysis. 16th edition. AOAC, International, Washington, DC.

2. Bourne, M. C. 1978. Texture profile analysis. Food Technol., 32:62-66, 72.

3. Chin, K. B., Lee, H. L., Kook, S. H., Yoo, S. S. and Chun, S. S. 2004. Evaluation of various combination of pork lean and water added on the physicochemical, textural and sensory characteristics of low-fat sausage. Food Sci. Biotechnol. 13:481-485

4. Jauregui, C. A., Regenstein, J. N. and Baker, R. C. 1981. A simple centrifugal method for measuring expressible moisture, a water-binding property of muscle foods. J. Food Sci. 46: 271-273.

5. SPSS. 2003. SPSS 12.0 for windows. SPSS Inc. USA.

6. 국성호, 최순희, 강상미, 박성용, 진구복. 2003. 젖산나트륨과 키토산을 첨가한 저지방 기능성 소시지의 냉장 저장 중의 품질 및 저장성 증진 효과. 한국축산식품학회지 23:128-136.

7. 김영아. 1992. 도토리 전분 및 전분겔의 형태학 적 특성 연구. 한국조리과학회지 8:9-14.

8. 김윤숙, 유익종. 1994. 저지방 육제품 개발에 대 한 연구동향. 한국축산식품학회지 14:110-116.
9. 김이영, 조후종. 2000. 도토리묵가루를 첨가한 도 토리떡의 품질특성에 관한 연구. 한국조리과학 회지 16:260-266.

10. 김일석, 진상근, 하경희, 류현지, 박기훈. 2005. 한국형 육가공 제품류의 물리적 및 관능적 품질 특성. 한국동물자원과학회지 47:49-56.

11. 류미라, 김은영, 정경숙. 2003. 홍국 첨가가 소시 지 품질특성에 미치는 영향. 한국식품과학회지 35:229-234.

12. 성인숙, 김명주, 조수열. 1997. 도토리추출물이 흰쥐의 체내 지질대사에 미치는 영향. 한국식품 영양과학회지 26:327-333.

13. 심태흠, 김영선, 사재훈, 신인철, 허성일, 왕명현. 도토리 가루의 성분분석과 항산화능 평가. 한국 식품과학회지 36:800-803.

14. 이유미. 1995. 우리가 정말 알아야 할 우리나무 백 가지: 3-23. 참나무. 현암사. p. 394-398.

15. 정인철, 강세주, 김종기, 현재석, 김미숙, 문윤희. 2003. 깻잎 분말 첨가와 도체등급이 돈육소시지 의 품질 및 기호성에 미치는 영향. 한국식품영양 과학회지 32:350-355.

16. 조성애, 김성곤. 2000. 도토리, 녹두 및 메밀전분 의 입도분포, 호화패턴과 겔특성. 한국식품과학 회지 32:1291-1297.

17. 진구복. 2002. 저지방 육제품의 제조 및 평가. 한 국축산식품학회지 22(4):363-372.

18. 진구복, 김화영, 김광현. 2005. 자몽 종자 추출물 을 첨가한 저지방 세절 소시지의 이화학적, 조직 적 특성 및 항균 효과. 한국축산식품학회지 25: 141-148.

19. 진구복, 왕승현. 2004. 키토산의 함량을 달리하여 첨가한 저지방 소시지의 품질 특성. 한국축산식 품학회지 24:361-366.

20. 최성희, 권혁추, 안덕준, 박정로, 오동환. 2003. 녹차분말 첨가 소시지의 아질산염 잔유량과 저 장성. 한국축산식품학회지 23:299-308.

(접수일자 : 2007. 10. 23. / 채택일자 : 2008. 3. 1.) 